\title{
A Fruitful Dialogue between Lutherans and Catholics in the South Land of the Holy Spirit
}

\author{
DEAN ZwECK*
}

Lutherans and Catholics in Australia have engaged in fruitful ecumenical dialogue for forty years, producing eight documents that have consistently had a view toward reception in the two respective churches. In recent years this Dialogue has been encouraged on its journey by the concept of receptive ecumenism. Ecumenical encounter is a work of the Holy Spirit, and each church can be enriched by recognising and receiving the charism of a partner church.

Keywords: fruitful ecumenical dialogue, receptive ecumenism, justification, dialogue documents, Sacrament and Sacrifice

\section{Introduction}

In 1606 the Portuguese navigator Pedro Fernandez Queirós landed on a Pacific island that he named "Australia del Espiritu Santo" (South Land of the Holy Spirit), thinking that it was the northerly part of a great southern continent that he was in quest of discovering. It was more than two hundred years later that European settlers officially adopted the name "Australia" for the island-continent, "discovered" long after Queirós, which they had forcibly occupied. Until recent times, no-one had thought to link it with the Holy Spirit, as the pious Queirós had done. On the contrary, Australia has sometimes been described as "the most godless place under heaven". While the Aborigines who had inhabited this continent for thousands of years were deeply spiritual people, the convicts and soldiers of the first British settlement were notoriously irreligious. Despite these inauspicious beginnings, Christianity did take root in Australian society and by the beginning of the twentieth century more than $90 \%$ of the population identified as Christian. There are numerous stories from the pioneering days of Christians reaching out to help each other across traditional denominational divisions in the isolation and harshness of those times. For example, there are stories of Protestants pitching in to help Catholics build their church, or everyone in a remote community turning up for the visit of a pastor or priest. From the beginning, denominational divisions in Australia were never as rigid as they were in the old countries of Europe.

\footnotetext{
* Rev. Dr. Dean Zweck, Lecturer Emeritus in Church History, Australian Lutheran College.
} Address: 104 Jeffcott St North Adelaide SA 5006 Australia, E-mail: dean.zweck@alc.edu.au 
Thus, it is not surprising that the ecumenical movement of the twentieth century was quite well received among Australian churches, although some were slow to get on board. Catholic participation blossomed only after the aggiornamento of Vatican II, and Lutherans, rent by bitter division for 120 years, finally began looking beyond themselves after coming together as one church in 1966 - the Lutheran Church of Australia (LCA).

One of the most fruitful ecumenical dialogues in Australia has been the one between just these two churches. In the wake of Vatican II, the Australian Catholic Bishops Conference in 1973 issued a tentatively worded invitation to the LCA to enter into dialogue. After some preliminary contacts, the first formal meeting of the Lutheran-Roman Catholic Dialogue in Australia was held in Adelaide in April of 1975. In October last year, the $186^{\text {th }}$ meeting of the Dialogue concluded with a celebratory luncheon to mark forty years of continuous and fruitful dialogue. A feature of this Dialogue has been a succession of documents that have been received by the two churches in various ways, and in some cases with notable results.

\section{The Dialogue Documents}

\section{Agreed Statement on Baptism (1977) ${ }^{1}$}

The first topic taken up by the fledgling Dialogue was Baptism. After two years of regular meetings - the pattern that developed was to meet four times a year - a brief document was produced that was not only well received by both churches, but immediately produced fruit at the deepest level: essential agreement on Baptism, leading to a recommendation that "formal and mutual recognition be given to baptism administered in our two church communities". ${ }^{2}$ The brief statement has six parts, from which we quote here a few key sentences:

"Baptism is a sacrament of the church, instituted by Christ. It is administered with water in the name of the Father and of the Son and of the Holy Spirit, in obedience to Christ's command (Matthew28:19). This sacrament incorporates the baptised into the Body of Christ, which is the church, and cannot be repeated. .... It grants birth to a new life, forgiveness of sins both original and actual, and the gift of the Holy Spirit... Through the gift of the Spirit and of grace, the baptised are immersed

\footnotetext{
1 "Agreed Statement on Baptism", Lutheran Church of Australia and Roman Catholic Church Conversations, unpublished document, Adelaide 1977.

2 Recommendation of the joint working group, cited in: The Southern Cross (7 October 1977), p. 1.
} 
in the saving events of the sacrificial death and resurrection of Christ...."

A feature of this first round of the Dialogue was that there was a specific recommendation to each church that was acted on promptly and decisively at the highest level, with the result that from that time both churches have recognised Baptism administered in both church communities. One of the Dialogue members, Fr. John O'Rourke, made this comment when the Statement on Baptism was made public:

"It marks a clear advance in declaring true unity that already exists between the two churches. While still separated in many areas of faith and worship, we are united as baptised Christian communities. We can, then, join as one body in prayer to our common Father and assist each other as brothers and sisters in work of charity and social concern. Our common prayer and Christian witness to charity will help us along the road to mutual understanding and may, please God, to eventual unity." ${ }^{4}$

Already at this beginning stage there is a concern to express the true unity that exists in Baptism in practical ways: prayer and co-operation in charitable work.

Sacrament and Sacrifice (1985)

The next topic taken up by the Dialogue was the Eucharist. After seven years of intensive study the Dialogue published, not an agreed statement or consensus document, but, more tentatively, a "report". Sacrament and Sacrifice was "offered as a report to the two churches from the dialoguing teams in the hope that it will lead to further discussion in the two communities" ${ }^{6}$ As the title indicates, the Dialogue focused on "Christ's presence in the Sacrament" and "Christ's sacrifice in the context of the Eucharist". In the Introduction the point is made emphatically that "the ultimate basis for all our discussions has been the witness of Holy Scripture", ${ }^{8}$ while at the same time acknowledging that the participants in dialogue "are bound by

\footnotetext{
3 "Agreed Statement on Baptism", paragraphs 1 and 2.

4 The Southern Cross, p. 1.

5 Sacrament and Sacrifice: A Report from the Lutheran-Roman Catholic Dialogue in Australia, Adelaide 1985.

${ }^{6}$ Ibidem, p. 3. The tentative nature of the report is further reflected in an "explanatory note" appended to copies sent to Lutheran readers.

7 Ibidem.

${ }^{8}$ Ibidem, p. 8.
} 
the official doctrines of their respective churches". ${ }^{9}$ Interestingly, despite the document being published as a "report", in the Introduction it is actually called "a joint statement on the Eucharist ... made before God" and thereby has the character of a "joint witness and confession".

It is a document of some 40 pages, eloquently written, and notable for its clarity. At its heart is a mutual confession regarding the Real Presence:

"Lutheran and Roman Catholic Christians hold in common the mystery of the real presence of Christ in the Eucharist as taught in Scripture. Our churches stress the real presence of Christ in the Eucharist to highlight the central purpose of the sacrament, namely, that the crucified, risen, and exalted Lord gives himself to us fully, draws us to himself, and shares with us his saving work and glorious life. These purposes are achieved by him when he gives us his body and blood by means of and in the Eucharistic bread and wine. We hold that this is the mutual confession of our churches." ${ }^{10}$

The document moves on to discuss "the place of change in affirming faith in the real presence". ${ }^{11}$ In view of the fact that transubstantiation was a matter of controversy for several centuries, the level of agreement and mutual understanding is quite surprising. Furthermore, it is significant that the word "sacrifice" appears already in the study's title. This indicates the Dialogue's willingness to deal with historically difficult issues in relation to the Eucharist.

It is difficult to ascertain to what extent this report was studied and received by the two churches. The tentative way in which it was offered does seem to indicate some apprehension, particularly on the Lutheran side. There was in fact no significant adverse reaction, and that in itself indicates a level of reception. Reception happens in all kinds of ways, often at the grass roots level in ways that cannot be known or measured. Let me give a personal example. When I was a parish pastor, a Catholic woman turned up on the doorstep of my office holding a copy of Sacrament and Sacrifice in her hand. She had been studying the document as part of the reading for a course she was doing. "You Lutherans really believe it, don't you! - you really believe in the Real Presence of Christ in the sacrament." "Yes, of course we do," I replied. And that was the beginning of a joyful and heartfelt conversation about our common faith concerning the Eucharist. Faith understands that

\footnotetext{
9 Ibidem.

${ }^{10}$ Ibidem, p. 14.

${ }^{11}$ Ibidem, p. 15-16.
} 
kind of mutual recognition of common faith and practice, and with it the welcoming of one another as sisters and brothers in Christ, as a work and a gift of the Holy Spirit.

\section{Pastor and Priest (1990) $)^{12}$}

After its work on Baptism and the Eucharist, it was almost predictable that the Dialogue would take up the question of ordained ministry: if we can agree on the essentials in our teaching about the two primary sacraments, are we able to recognise each other's ministry of word and sacrament? The Dialogue group became convinced that "full recognition of each other's ministry will need to occur as part of the process of reconciliation of churches". ${ }^{13}$ They saw their task as not only to work toward convergence on doctrinal matters, but also "to point the way toward reconciliation as the place where the issue of ministry is finally resolved". ${ }^{14}$

Again, much common ground was found regarding ordination and the function and task of ordained ministers in the church:

"We share the view that they are entrusted by God with the means of grace, and are called by him to render faithful service in many different ways as they carry out their ministry. They publicly proclaim the word of God and administer the sacraments of Christ, and seek to apply the gospel to the lives of the faithful. They are given a leadership role: in worship, in equipping the saints for service (Ephesians 4:11-16), in administering the affairs of the Christian congregation, and in representing Christ in the community.

As witnesses for Christ, the ordained ministers seek to spread the gospel and to reach out to the lost with the good news of salvation in Christ (2 Corinthians 5:20-6:3). They are examples to the flock, demonstrating by a life of love what it means to be a servant of the Lord Jesus (1 Timothy 4:11-16). They have a special ministry of spiritual healing through counselling, guiding, and forgiving sinners in the name of the Lord (John 20:21-23; Acts 2:38-41). In a very real sense, the mission and service of the apostles is continued through their ministries in Christian communities and in the world." 15

\footnotetext{
12 Pastor and Priest: A Report from the Australian Lutheran-Roman Catholic Dialogue on the Ordained Ministry in the Life of the Church, Adelaide 1990.

${ }^{13}$ Ibidem, p. 4.

${ }_{14}$ Ibidem.

${ }_{15}$ Ibidem, p. 12,13, paragraphs 43, 44; p. 12, 13.
} 
The differences, like the three-fold ordering of ministry or the understanding that ordination is a sacrament, are not ignored, but are discussed under headings like "Roman Catholic Emphases" and "Lutheran Emphases".

Highly significant is the understanding that this is not merely a dialogue about theology at an academic level. The last part of the document clearly outlines for both churches the task ahead:

"In view of this large measure of convergence, the task ahead focuses on two main issues. On the one hand, Roman Catholics need to reconsider their position on the authenticity of Lutheran orders, and the legitimacy of the ministrations and services rendered by this ministry. On the other hand, Lutherans need to reconsider the claims of the Roman Catholic Church concerning the essential nature of the threefold structure of ordained ministry and the value of episcopal ordination as a sign of apostolicity, catholicity, and unity of the church on earth." ${ }^{16}$

\section{Communion and Mission $(1995)^{17}$}

The participants in dialogue regarded the choice of this topic, which is essentially about the church, as "almost inevitable", ${ }^{18}$ since it had sat in the background from the very beginning: "Almost inevitably, then, the direction of our dialogue journey led us to the topic which has occupied our attention for the past five years: the doctrine of church in the light of our two traditions." ${ }^{19}$ Two important emphases in this Dialogue were: first, the agreement to focus on the concept of "communion" to describe and understand the church; secondly, the deliberate intent to address the doctrine of the church from the perspective of our mission in the world. After many years of dialogue, there is a touching acknowledgement on the depth of communio in the group itself:

"Those of us who have participated in this Dialogue testify that it has been a journey of faith. In meeting to discuss communion we have experienced communion. We have met each other before God, and we have known the gracious presence of God at the heart of our gatherings. We believe that this experience is but a

\footnotetext{
16 Ibidem, p. 17 (paragraph 64).

${ }^{17}$ Communion and Mission: A report from the Australian Lutheran-Roman Catholic Dialogue on the Theology of the Church, Adelaide 1995.

18 Ibidem, p. 3.

${ }^{19}$ Ibidem.
} 
promise and foretaste of what we will all share when, by God's grace, our churches are brought into full communion." 20

It is note-worthy that this study is offered for consideration not only by the two churches, but also by "the wider ecumenical community". ${ }^{21}$ The last section of the report, "The Next Step Together", recognises that "some issues relating to communio require further study", and in particular the following are mentioned: the relationship of the church to people of other faiths; the veneration and invocation of saints; and the possibility of recognising communio even when there are different organisational forms. ${ }^{22}$ Since true communio is "communion through the Gospel" it was proposed that the next step should be a dialogue about "the gospel and justification". ${ }^{23}$

Justification (1999)24

It is not too much to say that this "common statement" may well be the crowning achievement of the Lutheran-Roman Catholic Dialogue in Australia thus far. At the outset, it is important to recognise that, in presenting this document to the two churches and the wider ecumenical community, the language was notched up from "report" to "common statement".

Secondly, it is noteworthy that this document was published about the same time as, but independently and slightly ahead of, the international and much acclaimed Joint Declaration on the Doctrine of Justification. The consensus on justification in the Australian common statement is spelt out with admirable clarity:

"Lutherans and Roman Catholics together see justification as God's free and saving action in Christ whereby our sin is forgiven and we are both declared and made righteous. Together we confess that it is solely by grace and through faith that we are justified and not through our own merits. Together we say that justification cannot be separated from regeneration, sanctification, and the renewal of our hearts by the Holy Spirit. Together we affirm that justification, or salvation in Christ, is central and normative to our Christian faith." 25

\footnotetext{
${ }^{20}$ Ibidem.

${ }^{21}$ Ibidem.

${ }^{22}$ Ibidem, p. 25.

${ }^{23}$ Ibidem.

24 Justification: A Common Statement of the Australian Lutheran-Roman Catholic Dialogue, Adelaide 1999.

${ }^{25}$ Ibidem, part 3, p. 4-5.
} 
"Lutherans and Roman Catholics agree that apart from God's grace there is no justification of the sinner. We confess together that the sinner is justified on the basis of God's grace alone through faith in the saving act of God in Jesus Christ. The faith through which the grace of God works justification in the sinner can never be a mere intellectual assent. Justifying faith always includes trust in God's promise and is informed by love of God." 26

Thirdly, there was a strong emphasis on reception. The document was launched at a joint liturgy in St Xavier's Cathedral, Adelaide, which was packed to overflowing in response to concerted publicity in both churches. Furthermore, the document included an appendix - "Questions for Reflection and Study" - questions that were "designed to help group members reflect on and share their faith, promote an understanding of justification, and lead to an expression of faith in action." ${ }^{27}$ Catholics in Queensland took up this challenge by producing, on the basis of the appendix, an attractive study guide for use in parishes and schools. On the Lutheran side, the document was taken up for study in pastors' conferences, also in the hope that pastors would then lead studies in their parish settings.

\section{The Ministry of Oversight (2007) $)^{28}$}

After the euphoria of Justification came the disappointment of Dominus Iesus, the August 2000 declaration from the Vatican's Congregation for the Doctrine of the Faith that raised the question of the role of bishops in other churches or "ecclesial communities". A direct result of this was that our Australian Dialogue dropped the study of theological anthropology that it had embarked upon and turned its attention to an intensive seven-year study of the office of oversight in the church. The following paragraph sums up both the strong convergence we found and the place where we have differed:

"Lutherans and Roman Catholics agree on the divine institution of the pastoral ministry in the church. They agree that this apostolic ministry is conferred by a rite of ordination that includes the laying on of hands. They agree on the distinction within the one ministry of the pastor/priest and the president/bishop. Both churches see these as united in the one pastoral ministry of the church. Where we have differed is that Lutherans see the pastorate

\footnotetext{
${ }^{26}$ Ibidem, part 9, p. 10.

27 Ibidem, p. 12-16.

${ }^{28}$ The Ministry of Oversight: The Office of Bishop and President in the Church, Adelaide 2007.
} 
as a full expression of ordained ministry while Roman Catholics see the episcopate as the fullness of ordained ministry." ${ }^{29}$

A feature of this dialogue statement is a section at the end titled " $\mathrm{Fu}$ ture Steps". On the basis of the convergence that is to be found in the office of oversight, Lutherans and Catholics on the Dialogue put specific requests to each other's churches and to their own. For example:

"Lutherans ask Roman Catholics to respect their conviction that God has been with them in their church order and their pastoral ministry. Whether the title president or bishop is used, the office of oversight helps Lutherans to preserve and promote the primacy of the gospel of Jesus Christ by responsibly exercising a ministry of oversight in loving service of Christ and his church.

Roman Catholics hope that Australian Lutherans will come to share more fully with them in a common theology of the bishop in the life of the church. While this may involve a change of language from president to bishop, the more significant change would be part of that on-going reform, embracing in ever deeper ways the ancient common tradition of the church, in which the bishop was seen as sign and agent of communion in a local church." ${ }^{30}$

It was no small thing that Roman Catholic members of the Dialogue asked their church authorities "to consider that the Spirit of God might be leading them to recognise the authenticity of the Lutheran ministry and of Eucharistic celebrations of the Lutheran Church". ${ }^{31}$ Similarly, it was no small thing that Lutheran members asked their church "to remember that it was not the office of bishop that was at the heart of the Lutheran critique of bishops, but the way that the office was exercised in a particular historical situation. The Augsburg Confession does not call into question the office of bishop". ${ }^{32}$

This document was launched with a joint liturgy and celebration that was subsequently featured in articles that appeared in various church magazines, both Catholic and Lutheran. On the Lutheran side the document was sent out to all pastors and subsequently discussed at pastors' conferences. This reception of the Dialogue's work in the life of the LCA contributed in a major way to creating a favourable climate, so that at its Synodical Convention in April 2013 the LCA voted strongly to change the title for the office of oversight from "President" to "Bishop".

\footnotetext{
${ }^{29}$ Ibidem, p. 49, paragraph 116.

${ }^{30}$ Ibidem, p. 52, paragraphs 128-129.

31 Ibidem, p. 53, paragraph 133.

32 Ibidem, p. 54, paragraph 134.
} 
One area of discussion in the document on The Ministry of Oversight conspicuous by its absence is the topic of the role of the Bishop of Rome in the universal church. Already in 1995 Communion and Mission, in mentioning significant issues that still divided us, specifically named two: "the office of the Bishop of Rome and the doctrine of justification by faith". Justification was picked up forthwith (1995-1999), and at the time of this writing a document on the office of the Bishop of Rome is nearing completion.

\section{Living Word, Living Tradition (2011) ${ }^{33}$}

The question of the relationship between Scripture and Tradition has been present, sometimes in the background and sometimes to the fore, in the Lutheran-Roman Catholic Dialogue in Australia from its beginning in 1975. It was fitting, then, that this topic was taken up (2008-2011). The Dialogue's study and discussion centred on the nature of the word of God in the life of the church. The document makes a common affirmation of the Scriptures as the living word of God and explores the concepts of tradition that function in our two churches.

This round of the Dialogue was fruitful in that a high level of agreement was reached, and, given the long history of difference in this area, that is significant in itself. This is how the study was summed up:

"We believe that the level of agreement reached in this dialogue is significant for both our churches and for the relationship between us. Since the time of the Reformation, differences in our respective understanding of Scripture and Tradition have been church divisive. Joint study of these issues, taking account of developments since the sixteenth century, especially the impact of the Second Vatican Council and its Dogmatic Constitution on Divine Revelation, has enabled us to see beyond the original disputed questions and to understand each other in a new light. It has given us a richer, less controversial and more dynamic understanding of the word of God in the church. We have affirmed together that Scripture is the inspired word of God through which God speaks to us. We have also discovered a great deal of agreement between a post-Vatican II Roman Catholic theology of Tradition and the Lutheran concept of handing on the confession of the apostolic faith. Such affirmation and agreement attests to a common faith concerning the revelation of God and its transmission through the ages. We believe that recognition of a common faith will assist our engage-

${ }^{33}$ Living Word, Living Tradition, Lutheran-Roman Catholic Dialogue in Australia, Adelaide 2011. 
ment in the mission of God, so that the good news of salvation may continue to be received in our day." 34

The Dialogue offered the document to the two church, encouraging them "to begin the process of reception by studying its contents", and with the hope that "this will be an opportunity for the Roman Catholic Church and the Lutheran Church to see each other in a new light, that it will bring about further reconciliation between us, and that it will lead to deeper contact and cooperation between the two churches". 35

\section{Deeper Reception: Receiving the Charism of a Partner Church}

Over a period of forty years the Lutheran-Roman Catholic Dialogue in Australia has laboured faithfully and has been ecumenically fruitful: seven documents on major topics, with an eighth all but complete - and that on no less an historically contentious issue than the papacy. This is no small achievement. Moreover, throughout the forty years the Dialogue never became just an academic and theological enterprise. Beginning with Baptism, which immediately effected a notable change - mutual recognition of Baptism in each other's churches - there has been a constant concern that the Dialogue statements be received and studied to effect further reconciliation between our two churches. In the practical field, there have been a handful of Dialogue initiatives at the parish and regional level, joyful liturgical co-celebrations to launch Dialogue documents, and the heartfelt friendship and expression of communion that exist within the Dialogue group itself, and which radiates into both churches in various ways.

At the same time, it has to be recognised that reception has not been all what it could have been, or what the Dialogue group hoped their studies and statements might achieve. For this and other reasons some other ecumenical dialogues grew weary, went into recess or ground to a halt. Perhaps a little of that feeling of weariness has crept into our Dialogue too. However, in the last few years our Dialogue has been encouraged, renewed even, by a new movement in ecumenism that made its way from Durham in the United Kingdom, where it began, to the other side of the planet, to this "South Land". Although Australia cannot make much of a claim to be the "South Land of the Holy Spirit", the Spirit does indeed blow where it wills (John 3:8) even in this barren land. Receptive ecumenism proposes that ecumenical encounter between two church traditions needs to be understood as nothing less than an event of the Holy Spirit. Receptive ecumenism was not

${ }^{34}$ Ibidem, p. 24, paragraph 60.

${ }^{35}$ Ibidem, p. 24, paragraph 61. 
completely unknown at this end of the earth, but a visit to Australia in 2012 by Catholic lay theologian and founder of this new movement in ecumenism, Paul D. Murray, certainly got more people thinking and talking about it, also at the popular level. ${ }^{36}$

Two of the Catholic colleagues on our Dialogue, in particular, have picked up this concept, written articles about it, and read papers on it at conferences and meetings, etc. One of them,

One of them Fr. Denis Edwards, explains receptive ecumenism as follows:

"The notion of ecumenical receptivity is an invitation and a challenge to our churches. It proposes that the ecumenical encounter with another church tradition is an event of the Holy Spirit. In the otherness of the other tradition, the Spirit of God offers us a gift. In this understanding a central dimension of ecumenical action involves a stance of openness to the Spirit and the attempt to discern the Spirit. [...] Ecumenical receptivity encourages a stance before the other tradition that expects to find this tradition a place of grace. And the gift of the Spirit is to be found not only in the personal, but also in the structural and institutional dimensions of the other tradition." 37

The other colleague to have written and presented on receptive ecumenism is Fr. Gerard Kelly. In a public lecture before an ecumenical gathering Fr. Kelly described it as "a new wave in the ecumenical movement". ${ }^{38}$ He describes the advance in the ecumenical task in the form of a question:

"Given the consensus that has been reached in the ecumenical dialogue, what can my church learn from the other? [...] By and large the theological dialogues have produced important theoretical outcomes. Receptive ecumenism should take churches to the next step, building on these theoretical outcomes and looking for concrete expressions in each church's life." ${ }^{39}$

Both Edwards and Kelly use the dialogue on the doctrine of justification as an example, or test case, for receptive ecumenism in the Catholic Church. Citing Cardinal Walter Kasper, who, in the wake of the Joint Declaration on the Doctrine of Justification (JDDJ), said, "in the richness of the

\footnotetext{
${ }^{36}$ See Paul D. Murray (ed.), Receptive Ecumenism and the Call to Catholic Learning: Exploring a Way for Contemporary Ecumenism, Oxford 2008.

37 Denis Edwards, "Receptive Ecumenism and the Charism of a Partner Church: The Example of Justification", in: Lutheran Theological Journal 43 (3/2009), p. 167.

38 Gerard Kelly, "A new Ecumenical Wave", Public Lecture at the National Council of Churches Forum, Canberra 12 July 2010, p. 1.
}

39 Ibidem, p. 2. 
other we discover our own richness - this new perception and re-reception is a gift of the Holy Spirit, who leads us into the whole truth", Kelly then puts the question for Catholics: "How has our recent encounter with Lutheran and the doctrine of justification helped us to discover our own richness?" 40 This is no easy task, because how do we translate the sixteenth century experience of Martin Luther and his quest to find a gracious God into the language and experience of people today? Kelly concludes that reception of JDDJ in Catholic parishes and communities maybe less about doctrinal formulation and "more about human and spiritual experience, and about how we encounter God ... [and how] we help our people open up and interpret their experience, particularly the experience in many places of hopelessness and the search for meaning". ${ }^{41}$

In his appropriation of the doctrine of justification for our situation today, Edwards finds something truly precious in the Lutheran tradition to teach us about the life of faith:

"What is so liberating in all of this is Luther's discovery of a gracious God, a God who reaches out to us in Jesus Christ, bringing healing, forgiveness and peace. We can be freed from a troubled conscience because we no longer depend upon our own efforts, but depend radically on a God of grace and mercy." ${ }^{42}$

So, finally, what charism given to our partner church, the Roman Catholic Church, might Lutherans recognise and be enriched by in the South Land of the Holy Spirit? I do not think we Lutherans have yet had that discussion in any formal or serious way, so I can only offer a personal reflection. Having served on the Dialogue for about eighteen years, I feel that we as Lutherans have much to learn from the Spirit-given gift of Christlike graciousness, compassion and hospitality that I see in my Catholic colleagues and in the Catholic community. Sometimes as Lutherans we have interpreted sola fide in a way that isolates justification from any kind of response or renewal of life. Catholics have reminded us that in the life of faith justification does not stand alone: "Together we say that justification cannot be separated from regeneration, sanctification, and the renewal of our hearts by the Holy Spirit." ${ }^{43}$

${ }^{40}$ Ibidem, p. 9.

${ }^{41}$ Ibidem.

${ }^{42}$ D. Edwards, Receptive Ecumenism, p. 467. This quote is from the last part of Edwards's paper, which is actually an "Outline for a Homily on Justification". Edwards rightly regards the Sunday homily as having a crucial role in the process of reception, so he rounds off his paper with a superb little model homily on justification - one that any Lutheran pastor could be proud of?

43 Justification: A Common Statement, pp. 4-5. 